\title{
Yeşil Bankacılık ve Yeşil Krediler: Antalya'daki 4-5 Yıldızlı Otel İşletmelerinin Bakış Açıları Üzerine Bir Araştırma
}

\author{
Green Banking and Green Credits: An Investigation on the Perspectives of Four and Five Star Hotels in Antalya
}

\author{
Ozan GÜLER*, Ekrem TUFAN ${ }^{* *}$ \\ *Arş. Gör., Mersin Üniversitesi, Turizm Fakültesi, Çiftlikköy Kampüsü, Yenişehir, PK 33110, Mersin. \\ E posta: ozanguler@mersin.edu.tr \\ ** Doç. Dr., Çanakkale Onsekiz Mart Üniversitesi, Turizm Fakültesi, Terzioğlu Kampüsü, PK 17100, Çanakkale. \\ E posta: etufan@yahoo.com
}

\section{MAKALE BILGILERI}

Makale ișlem bilgileri:

Gönderilme tarihi: 16 Aralık 2013

Birinci değerlendirme: 12 Mart 2014

Kabul: 22 Mart 2014

Anahtar sözcükler:

Yeşil bankacılık, Yeşil kredi, Otel performansları, Turizm, Antalya.

\section{ÖZ}

Doğal çevre ve kaynakları koruyan yatırımların desteklenmesi için ayrılan özellikli kaynaklardan biri olan yeşil kredilere otel işletmelerinin bakış açılarının araştıııldığı bu çalışmada, amaçlı örnekleme tekniği kullanılarak 142 finans müdüründen anket formu aracılığıyla veri toplanmıștır. İșletmelerin yeșil yatırımlardan bekledikleri getirileri araştıran nitel çalışmalardan yararlanılarak geliştirilen 16 performans göstergesinin, otellerin mevcut ve yeşil kredi kullanma durumlarına göre değişimi araştırılmıştır. Temel istatistiklerin yanı sıra, araştırmada eşleştirilmiş t-Testi, açımlayıcı faktör analizi ve doğrulayıcı faktör analizi gerçekleştirilmiştir. Araştırma sonuçlarına göre, katılımcıların mevcut durumda "sosyal", "ekonomik" ve "maliyet kontrolü" faktörleri altında algıladıkları performans göstergelerini, yeşil kredi kullanmaları durumda "sosyal ve ekonomik" ve "maliyet kontrol" olarak iki faktör altında algıladıkları anlaşıımıştır. Ayrıca, yeşil kredi kullanma durumunda en olumlu performans değişiminin "rekabet avantajı elde etme", "maliyet kontrolü" ve "sosyal itibar" göstergelerinde gerçekleștiği buna karşın "kurumsal ekonomik itibar" ve "borçları ödeme gücü"nün yeșil kredi kullanma durumuna göre istatistiksel olarak anlamlı değișiklik göstermediği ortaya çıkmıştır.

\begin{abstract}
This study delves into hotels' perspective on green credits that are one of the specialized funds to support investments saving natural environment and resources. Data has been collected through questionnaires from 142 financial managements by using purposing sampling method. 16 performance criteria developed from hotels' expectations of green investment, has been evaluated by the participants considering their hotels' current and possible usage of green credit situation. In addition to basic statistics, paired sample t-Test, explanatory and confirmative factor analyses are applied. As a result of the study, it has been understood that, while in the current situation of the hotels, performance indicators have been perceived under three factors, which are "social", "economic" and "cost control", same indicators are perceived under two factors those are "social and economic" and "cost control" in presumption of using green credit. Moreover, the most significant positive performance differentiation has been observed among the "to get advantage of competiveness", "cost control" and "social reputation" indicators, in presumption of using green credit. The indicators "corporative economical reputation" and "capacity to pay debt" however, show no significant differentiation in terms of using green credit.
\end{abstract}

\section{GiRiş}

Dünyada sınır kavramının azalması, ulaşım olanaklarının artması, insanların farklı kültürleri tanıma arzusu ve boş zamanlarının artması, seyahatlerde demokratikleşme ve teknolojik gelişmeler, turizm hareketlerine büyük bir ivme kazandırmıștır (Yılmaz 2007; Usta 2008). Zaman içerisinde turizmin sağladığı getirilerinden pay almak isteyen ülkeler ve bölgeler; tarihi, kültürel, sosyal ve çevresel tüm çekicilik unsurlarını turizm ürünü ola- rak sunma yarışına girmiştir. Bu yarış sonucunda ortaya çıkan plansız ve kontrolsüz gelişmeler, 1970'li yılların başında uluslararası konferanslarda konu edilmeye ve turizmin geleceği açısından tartışılmaya başlanmıştır. Özellikle kitle turizmindeki hızlı artışın olumsuz etkilerinin ortaya çıkması ile birlikte çevreye sorumlu davranışı, doğal kaynakları adil bir şekilde tüketmeyi ve yerel toplumların sosyo-kültürel yapılarını korumayı amaçlayan sürdürülebilir yeșil-çevreci turizm modelleri üzerinde 
durulmuştur (Forsyth 1997; Garrod ve Fyall 1998; Akış 1999; Swarbrooke 1999; Modinos 2000).

Bu gelişmelere ek olarak dünyanın ciddi biçimde etkilenmekte olduğu kirlenme ve küresel ısınma gibi çevresel sorunlar da turizm endüstrisinin iş yapış şeklini mecburen değişmeye itmiştir. İşletmeler zamanla iş yapış şekilleri, etik değerleri ve sosyal sorumlukları ile yargılanmaya ve ortaya çıkan sosyal ve çevresel olumsuzlukların sorumlusu olarak görülmeye başlanmıştır. Dolayısıyla çevresel ve sosyal sorunların farkında olan insanlar, turizm endüstrisinden de bu doğrultuda hareket etmesini bekleyerek, işletmeleri sürdürülebilir faaliyetlere yönlendirmiştir (Lee vd. 2010). Ek olarak, uluslararası çevre konferanslarında yapılan tartışmalarda sürdürülebilirliğin finansal boyutu da dikkate alınarak, finans kuruluşlarından kaynaklarını sürdürülebilir yatırımlara yöneltmeleri (White 1996) ve ülkelerden finans-bankacılık sektörlerini bu konuda teşvik etmeleri istenmiştir (Aizawa ve Yang 2010).

Bu çalışmada, turizm endüstrisi için yeni bir finansal araç olarak görülen yeşil kredilerin, otel işletmelerinin performanslarında meydana getirebileceği değişiklikler araştırılmıştır. Bu kapsamda öncelikle finans sektöründe sürdürülebilirlik, sürdürülebilir bankacılık, yeşil bankacılık ve yeşil kredi kavramları anlatılmıştır. Literatür taramasında işletmelerin geleneksel ve yeşil kredilerden beklentileri üzerinde durulduktan sonra çalışmanın alan araştırması bölümünde, Antalya'da faaliyet gösteren 4-5 yıldızlı otel işletmelerinden toplanan veriler analiz edilmiştir. Son olarak, bulgular yorumlanarak kuramsal ve yönetsel çıktılar ortaya koyulmuştur.

\section{KURAMSAL ÇERÇEVE}

\section{Finansta Sürdürülebilirlik Anlayışının Gelişimi ve Sürdürülebilir Bankacılık}

Verdikleri finansal yatırım ve borç verme kararları nedeniyle ekonomik kalkınma, çevresel koruma ve sosyal sorumluluk konularında önemli roller üstlenen finansal kuruluşlar için (Sullivan ve O'Dwyer 2009; Kurt 2009) sürdürülebilirlik kavramı karar alma ve borç verme aşamalarında "sosyal ve çevresel riskleri" yönetme anlamı taşır (IFC 2007). Sürdürülebilirlik, finansal kuruluşlarının sistematik ve sistematik olmayan risklerini yönetmesinde oldu- ğu kadar finansal ürün çeşitliliği ile diğer endüstrilerin doğal, ekonomik ve sosyal çevreye etkilerini şekillendirmesinde rol oynar. Uluslararası Finans Kurumu (IFC) (2007) sürdürülebilir finansı "finansal sermayenin ve risk yönetiminin, ekonomik zenginlik, çevresel koruma ve sosyal adalete zarar vermeyecek ve bunları teşvik edecek projelere aktarılması" şeklinde tanımlamıştır.

İşletmeler için finans sektöründe yer alan bankacılık sisteminde görülen aksamalar ya da olası belirsizlikler, ekonominin tüm unsurlarını olumsuz etkiler. Aynı zamanda bankacılık sektörü çevresel ve sosyal yatırımları desteklemesi bakımından kilit bir role sahiptir (Sahoo ve Nayak 2008). İlk bakışta çevreye bir zararı olmayan, çevreyi kirletmeyen ya da zararlı atık üretmeyen bir sektör olarak görülen bankacılık sektörü için çevre konusu, kendi iç çevresel yönetimi ile sınırlı gibi görülebilir. Buna karşın bankaların finanse ettikleri yatırımlar çevreye doğrudan veya dolaylı zararlar verebilir (Thompson 1998; Cowton ve Thompson 2000). Bu zararları ortadan kaldırmak veya en aza indirebilmek için bankaların sürdürülebilirlik kapsamında doğal ve beşeri çevreyi korumaya yönelik yatırım projelerini desteklemesi önem taşımaktadır. Bu bağlamda, Bouma vd. (2001) tarafından sürdürülebilir bankacllık; "finansal hizmet ve ürünlerin, aktivitelerinden doğabilecek çevresel ve sosyal etkileri hesaba katan şahıs ve işletmelere sağlanması" şeklinde tanımlanmıştır. Sürdürülebilirlik bankacılık faaliyetleri; çevre dostu yatırımların kurumsal sosyal sorumluluk anlayışı ile desteklendiği ve çevresel raporların düzenlendiği "yeşil bankacılık" faaliyetlerinin önünü açan bir yaklaşım olmuştur (Bouma vd. 2001).

\section{Yeşil Bankacılık}

Scholtens (2006), çevre dostu proje finansı olarak adlandırdığı bu bankacılık faaliyetini, doğal ve beşeri çevrenin korunması ve gelişimi öncelikli olmak üzere kaynakların korunmasını önemseyen ve destekleyen yatırım projelerine finansal kaynak tahsis edilmesi olarak ifade etmektedir. 1980'li yıllarda Amerikan bankalarının, mahkemeler tarafından doğrudan ya da dolaylı çevresel zarara yol açtığ 1 için büyük tutarda para cezasına çarptırılması, yeşil bankacılığın çıkış noktası olarak kabul edilebilir (Sahoo ve Nayak 2008). 11 Kasım 1980 tarihinde Amerikan Kongresi tarafından çıartılan 
CERCLA Yasası ile halk sağlı̆̆ını ve çevreyi kirleten endüstrilerin sahipleri ve bankalar suçlu bulunarak işletmelere fon sağlayan bankalar tazminat ödemeye mahkûm edilmiştir (Weber 2008). Öyle ki bazı bankalar için verilen ceza tutarları, sağladıkların finansal kaynağın tutarını büyük ölçüde aşmiştır (White 1996; Case 1996 aktaran Cowton ve Thompson 2004).

Scholtens (2006) ve Sahoo ve Nayak'ın (2008) ifadelerinden yola çıkarak yeşil bankacılık, işletmeleri daha çevreci politikalar uygulamaya iten, doğal çevrenin korunmasını esas alan ve çevresel ve sosyal sorunları azaltıcı yatırım projelerini destekleyici bir finansal araç olarak ifade edilebilir. Ülkelerin yüzleştiği çevresel, sosyal veya kültürel bozulmaların yoğunluğuna göre, kaynakların ayrımı değişiklik gösterebilir. Örneğin, 1988 yılında Almanya'da kurulan dünyanın ilk yeșil bankası olan Ökobank fonlarını çevresel sorunlar, sosyal adalet, eğitim ve eşit fırsatlar konularına yönlendirmişken, Amerika'da kurulan South Shore Bankası kaynaklarını yağmur ormanlarını koruma temeline dayandıran ve çevresel ve ekonomik kalkınmaya öncelik veren yatırımlara yönlendirmiştir (White 1996). Yeşil bankacilık stratejisini benimseyen bankalar, yatırımlara fon sağlarken uygulanan geleneksel firma ve proje risklilik kontrolünün yanı sıra, toplumun desteklediği ve aynı zamanda çevreye de faydalı olabilecek projelere kaynak sağlayarak çeşitli endüstriler için yeni finansal kaynaklar yaratmaktadır (Sahoo ve Nayak 2008).

\section{Yeni Bir Finansal Araç Olarak Yeşil Kredi}

Son yıllarda küresel ısınma, kuraklık, bitki ve hayvan türlerinde azalma gibi pek çok şiddetli çevresel sorunun sosyal ve ekonomik kalkınmayı etkilemesi sebebiyle (Aizawa ve Yang 2010), sürdürülebilirlik ve sürdürülebilir kalkınma anlayışını geliştirici yatırımlar, dünya çapında desteklenmeye başlamıştır. Dünya Bankası (DB), Avrupa Yatırım Bankası (AYB), Eximbank, Fransız Kalkınma Ajansı (FKA), Japon Kalkınma Bankası (JKB), Alman Kalkınma Bankası (AKB) vb. birçok finansal kuruluş, belirli koşullar altında farklı sektörlere ait projelere kaynak sağlamaya başlamıştır. Bu kaynaklar genellikle, sendikasyon kredisi başlı̆̆ı altında, ülkelerdeki finans kuruluşlarına aktarılmaktadır ve riskler ülkede faaliyet göstererek kaynağa aracilık eden bankalara aittir. Projelerin onaylanmasının nihai ka- rarı, fonu ülkeye aktaran finans kuruluşuna aittir. Son zamanlarda sağlanan kaynakların çok büyük kısmı KOBİ kapsamına giren yatırımlara, enerji verimliliği ve yenilenebilir enerji projeleri hazırlayan işletmelere aktarılmaktadır. Özellikle işletmelerin daha rekabetçi fiyatlarla enerji tüketimini sağlayan yenilenebilir enerji ve enerji verimliliği projelerine ayrılan kaynaklar son yillarda oldukça artmıştır (Haralambopoulos ve Polatidis 2003). Özellikli krediler olarak nitelenen yurt dışı kaynaklı kredilerin yanı sıra ülkelerin kendi finans kuruluşlarının ve ticari bankalarının "sektörel destek paketleri" de mevcuttur. Temelinde ödemesiz dönem kolaylığ1na sahip olan bu kredilerin, her finansal kuruluş ve bankanın kendi sübjektif değerlendirmeleri sonucu kullandırıldıkları için yeşil kredi olarak adlandırılmaları doğru olmayacaktır.

Yeşil kredi tanımının hangi tür kredileri kapsadığına bir örnek vermek, tanımının daha anlaşılır olmasını sağlayabilir. 2007 yılında Çin Halk Cumhuriyeti Çevre Bakanlığı, Çin Bankalar Birliği Düzenleme Kurulu ve Çin Halk Bankası bir araya gelerek Çin'deki tüm bankalara fonlarını, doğal ve enerji kaynaklarını aşırı tüketen ve/veya kirliliğe sebebiyet veren firmalara, imtiyazlı şartlar ile proje hazırlanması koşuluyla kullandırmak üzere saklamalarını dikte eden "yeşil kredi politikasını" duyurmuştur (Aizawa ve Yang 2010). İşte bu tür çevresel ve sosyal bozulmayı durdurmak veya azaltmak amacıyla, projelendirilmiş yatırım başvuruları ile belirli çevresel ve sosyal sorumlulukları yerine getirme şartını taahhüt eden başvurulara, özel imtiyazlar ile kullandırılan uzun vadeli kredilere "yeşil krediler" denmesi uygun olacaktır. Bu nedenle, DB, AYB vb. kuruluşların kullandırdıkları krediler "yeşil kredi" olarak adlandırılabilirken, çevresel ve sosyal fayda yaratmak amacindan uzak, yalnızca finansal bir ürün çeşitlendirmesi olarak görülebilecek sektörel destek kredileri, "yeşil kredi" olarak değerlendirilmemelidir. Yeşil kredinin diğer kredilerden ayrılan yönü, finansal kaynak sahibinin (örneğin Dünya Bankası) dikte ettiği çevresel, sosyal, kültürel ve ekonomik bozulmalardan herhangi birinin azaltılmasını taahhüt eden projelere fon sağlamasıdır.

Türkiye'deki yeşil krediler Dünya Bankası, Avrupa Yatırım Bankası, Avrupa Konseyi Kalkınma Bankası, Alman Sanayileşme Fonu, Fransız Kalkınma Ajansı, Avrupa İmar ve Kalkınma Bankası gibi uluslararası finans kuruluşları tarafından verilmek- 
tedir. Bu kredilerin yatırım projelerine aktarılmasına Türkiye'de faaliyet gösteren özel bankalar, Türkiye Kalkınma Bankası, Türkiye Sınaî ve Kalkınma Bankası, Türk Eximbank, Türkiye Sürdürülebilir Enerji Finansmanı, Küçük ve Orta Ölçekli İşletmeleri Geliştirme ve Destekleme İdaresi Başkanlığ1 (KOSGEB) ve Turizm Bakanlığı gibi özel ve yarı özel kamu kurumları aracılık etmektedir.

\section{ALANYAZIN TARAMASI}

\section{Geleneksel ve Yeşil Banka Kredilerinin İşletmelerin Performanslarına Etkisi}

İşletmelerin, sadece özkaynaklar ile finanse edilmeleri hemen hemen mümkün değildir. Bu anlamda bankacılık piyasası kapitalist sistemde vazgeçilmez bir yere sahiptir. Özkaynakları yetersiz olan işletmeler ya sermaye piyasasına ya da bankacilık piyasasına yönelmek durumundadırlar. Bankacılık piyasası, sermaye piyasasına göre daha hizlı ve kolay kaynak sağlayabildiği ve küçük işletmelerin sermaye piyasasına girme şanslarının neredeyse olmaması nedeniyle büyük öneme sahiptir. Alanyazında, küçük işletmelerin kredi anlaşmalarını birden çok banka ile yaptıkları gözlenmektedir. Ogawa vd. (2007) bu durumu Japonya için de gözlemleyerek yüksek borçlu ve nakit sıkıntısı çeken işletmelerin birden çok banka ile çalıştığını belirtmektedir. İsveç'te ileri teknoloji alanında yer alan 183 küçük işletmenin temel sermaye desteğinin de benzer şekilde bankalar tarafından karşılandığ1 gözlemlenmiştir (Aaboen vd. 2006). Öte yandan, ABD'de yapılan bir çalışmaya (Hooks, 2003) göre ise küçük işletmelerin aynen Japonya'da olduğu gibi bankalarla daha fazla kredi sözleşmesi yapmak zorunda kaldıklarını büyük işletmelerin ise eğer bankalardan aldığı kredi bilgisi dışarıdan kolayca elde edilemiyorsa, krediyi yoğun bir şekilde kullandıklarını ifade etmiştir. Dolayısıyla, bankalardan kredi kullanmak küçük işletmeler için bir zorunluluk iken büyük işletmeler için ise kısmen itibar kaybı olarak algılanmaktadır. Bu sebeple Hooks (2003), işletmelerin itibarlarının korunması hususunda devlet otoritelerine iş düştüğünü belirtmektedir.

Avrupa'da faaliyet gösteren 683 işletmenin verilerinden hareketle yapılan araştırmada, banka kredisi kullanımı ile varlık kârlılığ 1 arasında bir ilişki olduğu sonucu bulunmuştur (Krivogorsky vd. 2009). Bununla beraber Almanya için yapılan bir araştırma, bankalarla içli dışlı olan işletmelerin sermaye sıkıntısı çekmediklerini kanıtlarken, daha kârlı ya da daha hızı büyüme performansı göstermeleri yönünde bir kanıt bulamamıştır (Agarwal ve Eltson 2001). Banka kredisi kullanımının işletmeler açısından yararlı olup olmaması, işletmenin faaliyet gösterdiği bölgenin sosyo-ekonomik gelişmişliği ile doğrudan ilintilidir (Ferri ve Messori 2000). Bankalarla güçlü işbirliğine sahip işletmelerin, nakit akımlarına karşı daha az duyarlı oldukları ve gelecekte yapacakları yatırımları için kasalarında daha az nakit bulundurdukları belirlenmiştir (Shen ve Wang 2005). Bununla beraber, llımlı borçlanma işletmelere rekabet üstünlüğü sağlarken, yüksek oranda borçlanma ise işletmelerin piyasadaki başarılarını düşürmektedir (Campello 2006). Japonya'da yapılan bir araştırmaya göre (Yao ve Ouyang 2007), ekonomik sıkıntı çekilen 1990'larda, bankalar kâr istikrarlarını sağlamak için müşterilerini aşırı borçlanmaya ve yatırım yapmaya zorlamıştır. Ek olarak Yao ve Ouyang, (2007) aynı dönemde kredi kullanan işletmelerin finansal performanslarının olumsuz etkilendiğini ifade etmiştir.

Buna karşın geleneksel banka işletme ilişkisi son yıllarda farklı bir boyuta geçerek, sürdürülebilirlik kavramı çerçevesinde şekillenmeye başlamıştır. Gerek kredi sağlayanlar gerekse kredi talep edenler için yatırımların sürdürülebilirliği önemli bir ön koşul olmaya başlamıştır. Yasal düzenlemeler, artan işletme maliyetleri, işletmelerin aktivitelerinden kaynaklı olumsuz ekolojik etkilerin farkına varması ve paydaş baskısı gibi nedenler işletmelerin doğal çevreye karşı bakış açılarını stratejik olarak yeniden gözden geçirmelerine sebep olmuştur (Kassinis ve Soteriou 2003). İşletmelerin çevreci olmayan yatırımları çeşitli yollardan gelir kaybetmelerine de yol açmıştır. Heinkel vd. (2001) yaptığ araştırmada işletmelerin etik yatırımlar yapmamaları veya teknolojilerini yenilememeleri yüzünden yeşil yatırımcıların ilgili işletmelerin hisselerine daha az ilgi gösterdiklerini ve bu nedenle çevreyi kirleten işletmelerinin senetlerinin değerinin düştüğ̈nü ifade etmektedir. Yazarlar, bu durumun işletmelerin sermaye maliyetlerini arttırdığını ve bu sebeple işletmelerin zorunlu olarak yeşil yatırımlara yöneldiğini ifade etmektedir. Bir işletmenin hisse senetlerinin $\% 25$ 'inin yeşil hisse olmasının yenileme maliyetleri için yeterli olduğunu ifade eden 
Heinkel vd. (2001) buna karşın işletmelerin sahip olduğu yeşil hisse oranının \%10 civarında olduğunu ifade etmektedir.

Philips ve Philips (2011), işletmeleri sürdürülebilir projelere iten en önemli güdülerden birinin kamuoyu önündeki imajları olduğunu ifade etmektedirler. Berns vd. (2009) araştırmalarda işletmeleri sürdürülebilir yatırımlara yönelten faktörleri önem sıralarına göre; işletme ya da marka imajı, maliyet tasarrufu, rekabet avantajı, çalışan memnuniyeti, ürün ve pazara yönelik yenilikler, iş veya sürece yönelik yenilikler, yeni gelir ya da nakit akışı ve etkin risk yönetimi şeklinde sıralamıştır. Bununla birlikte yeşil yönetim şeklinden etkilenmiş olan finans kuruluşlarının da finansal kaynaklarını çevresel risk içeren projelere aktarmamaya başlaması, turizm endüstrisi içerisinde yer alan sektörleri çevre dostu projelere yönelmeye iten bir diğer faktör olmuştur (Roarty 1997'den aktaran Faulk 2000: 4). Penny'nin (2007) otel genel müdürleri ile yapmış olduğu çalışmasında, katılımcıların \%65'i sürdürülebilir yatırımların işletmelerin imajı ve rekabetçiliğine katkı yapan bir unsur olduğunu düşünmektedir. Çalışmada, sürdürülebilir yatırımlar için katlanılan girişim maliyetinin istenilen değeri yaratabilmesi için, maliyet kontrolünün önemli bir husus olduğu ancak bir yatırım projesini tek başına değerli kılacak kadar önemli algılanmadığı anlaşılmaktadır.

Bu açıdan geleneksel kredilerin işletmelere sağlayacağı getirilerin doğrudan ekonomik beklentilere yönelik olduğu söylenebilirken, sürdürülebilir yatırımları destekleyen yeşil kredilerden beklentilerin ekonomik beklentilere ek olarak işletmelerin bilinirliğinin artması ve toplum gözünde daha olumlu imaj elde edilmeye çalışılması gibi halkla ilişkiler ve sosyal sorumluluğa yönelik beklentiler de söz konusudur. Geleneksel kredileri kullanmak büyük işletmeler açısından duyulması fazla istenen bir durum değilken yeşil kredi kullanmak küçük ya da büyük her işletme açısından itibar arttıran bir durum olabilir.

\section{YÖNTEM}

\section{Araştırmanın Amacı}

Bir işletmenin varlığını ve rekabet edebilirliğini korumak ve geliştirmek adına yapacağı yatırımları (Usta 2005), en uygun kaynak bileşimi ile ger- çekleştirebilmesi (Akgüç 1998; Ceylan ve Korkmaz 2008) piyasa değeri üzerinde önemli etkiler gösterir (Usta 2005). Yatırım harcamalarının işletmeye sağlayacağı yararların zaman içinde dağılımı ve yatırımın ekonomik ömrü gibi (Akgüç 1998) finansal göstergelere göre isabetli yatırımlara yönelmek ve sermayenin en rasyonel ve uygun (bedellerin en az, getirinin en çok) biçimde kullanılması oldukça önemlidir (Usta 2005). Dolayısıyla işletmelerin dış kaynak kullanımı bağlamında kullanacağı kredinin türü oldukça kritiktir. Son dönemde yaygınlaşan bir kaynak olan çevre dostu krediler, diğer adıyla yeşil krediler işletmelere önemli avantajlar sağlayan kredilerdir. Kullandırma şartı olarak işletmelerin faaliyetlerinden kaynaklı zararları en aza indirme, doğal-beşeri kaynakları dengeli kullanma ve enerji verimliliği gibi vaatleri taşıyan yeşil krediler, buna karşılık faiz oranı, vade ve geri ödemesiz dönem gibi olumlu özelliklere sahiptir. Bu çalışma kapsamında, yatırımlara finans kaynağı sağlamada yeni bir araç olan yeşil kredilere potansiyel müşteri olabilecek otel işletmelerinin bakış açıları araştırılmıştır. Evren ve örneklem olarak otelcilik sektörünün seçilmesinin üç temel sebebi vardır. Birincisi turizm endüstrisinin küresel ısınma ve benzeri çevresel faaliyetlerden en çok etkilenen endüstrilerden biri olması, ikincisi otelcilik sektörünün doğal ve beşeri kaynaklara olan yüksek bağımlılığı ve üçüncü olarak tüm dünyada otelcilik sektörünü yeşil işletmeler olmaya iten Yeşil Yıldız, Ecofriendly Hotels Worldwide, Ecotel ve Green Globe, Green Key, Green Leaf ve LEED gibi sertifika programlarının yaygınlaşmış olmasıdır. Bu sebeplerle, yeşil olmak isteyen işletmeler için yeşil kredilerin kullanılması uygun bir kredi türü olduğuna kanaat getirilmiştir. Sonuç olarak da bu kredi türünün otellerin finans yöneticileri tarafından nasıl algılandığının ve otellerin performanslarında nasıl bir değişime neden olabileceğinin araştırılmasının önemli olabileceği düşünülmüştür.

$\mathrm{Bu}$ amaç çerçevesinde öncelikle performans göstergelerinin mevcut durum ve yeşil kredi kullanma durumuna göre hangi boyutlar altında algiland1ğı araştırılmaktadır. Ek olarak otellerin yeşil kredi kullanılması durumunda, mevcut duruma kıyasla hangi performans göstergelerinde anlamlı değişimler oluşacağının ve yeşil kredi kullanmanın genel performansı ne yönde değiştireceğinin ortaya koyulması amaçlanmıştır. Çalışma, Türkiye'deki 
otellerin yeşil kredilerden yararlanmalarının çeşitli performanslarına etkilerinin incelenmesi ve geleneksel krediler ile yeşil kredilerin performansa etkileri açısından yaptıkları karşılaştırma bakımından alanyazına katkı sunmaktadır.

\section{Araştırmanın Evren ve Örneklemi}

Araştırma evreni olarak, Antalya'da faaliyet gösteren 4 ve 5 yıldızlı otel işletmeleri belirlenmiștir. T.C. Başbakanlık Bilgi Edinme Birimi'nden alınan bilgiye göre, 2012 yılı Nisan ayında Antalya'da aktif olarak faaliyet gösteren 451 adet 4 ve 5 yıldızlı otel işletmesi mevcuttur. $\% 5$ anlamlılık düzeyinde \%5 örneklem hatası ile her iki birimden birine ulaşma olasılığını (P:0,5 ve Q:0,5) göz önünde bulundurarak hesaplanan sinırlı örneklem hacmine göre (Karasar 2005) ulaşılması gereken örneklem büyüklüğü 249 işletme olarak tespit edilmiştir. Ön testlerin tamamlanıp, anket formuna son şeklinin verilmesinin ardından, araştırmanın evrenini oluşturan 451 adet 4 ve 5 yıldızlı otelin finans müdürlerinden 348 tanesi ankete katılmayı kabul etmiştir. Elektronik ortamda oluşturulan anketin internet adresinin, kişilerin elektronik postalarına gönderilmesiyle veri toplama süreci başlatılmıştır. Tüm katılımcilara üçer defa hatırlatma amaçlı bilgi mesaj1 gönderilmiştir. Anket toplama dönemi sonunda gönderilen 348 anketten 150 tanesi geri dönmüştür. Sonuç olarak ankete katılmayı kabul eden kitleden \%43'lük bir geri dönüş elde edilmiştir. Elde edilen veri havuzundan, eksik ve hatalı doldurulduğu anlaşılan 8 adet anket formu çıkartıldıktan sonra 142 anket geçerli olarak kabul edilmiş ve analize tabi tutulmuştur. Araştırmacının amacına uygun daha küçük sayıda örneklemi içermesi ve konu hakkında daha fazla bilgi sahibi katılımcının seçilmesine olanak sağlaması (İslamoğlu 2009; Kuş 2009) nedeniyle araştırmanın örnekleme tekniği olarak olasılıksız örnekleme yöntemlerinden amaçlı örnekleme tercih edilmiştir.

\section{Veri Toplama Yöntemi ve Soru Formunun Hazırlanması}

İki bölümden oluşan anketin, ilk bölümünde katılımcılardan otellerinin performans göstergelerini mevcut durumlarına ve yeşil kredi kullanmaları durumuna göre değerlendirmeleri istenmiştir. $\mathrm{Bu}$ çalışmanın amacıyla ilgili alanyazında daha önce yapılan bir çalışmaya rastlanmamış olması ne- deniyle veri toplama aracı olarak, Tzchentke vd. (2004) tarafından İskoçya Yeşil Turizm İşletmelerine üye 30 otelin genel müdürü ve sahipleri ile yapılan "işletmeleri yeşil işletme olmaya yönelten nedenler" isimli nitel çalışma bulgularına ait 12 unsur ve yazarlar tarafından sekiz yeşil otel ile yapılan görüşmeler sonucunda ortaya çıkan dört unsur ("sezonluk yenilik yapabilme", "doluluk oranı", "operatör ve acentalarla pazarlık gücü" ve "pazarlama yönetimi") olmak üzere toplam 16 performans göstergesinden oluşan anket formu kullanılmıştır. Bu göstergeler, Likert tipinde 5'li olarak derecelendirilmiş ve katılımcılardan ilgili ifadeleri, $1=$ =çok kötü, $5=$ =çok iyi, olacak şekilde değerlendirmeleri istenmiştir. Katılımcılardan her bir performans göstergesini öncelikle mevcut durumlarına göre değerlendirmelerinin ardından aynı göstergeyi ankette yer alan özellikteki yeşil krediyi kullandıkları varsayımına göre tekrar değerlendirmeleri istenmiştir. Böylelikle işletmelerin yeşil krediyi kullanarak katlanacakları maliyetler ile elde edecekleri performans çıktılarını karşılaştırmaları sağlanmıştır. Önerilen yeşil kredi, Antalya'da faaliyet gösteren çeşitli bankaların kredi bölümü yöneticileri ile yapılan telefon görüşmeleri ve bankaların internet sitelerindeki kredi kullandırma koşulları göz önünde tutularak hazırlanmıştır. Buna göre değerlendirilmesi istenen yeşil kredi; yatırım kredisi bağlamında (ek bina, yenileme, ünite yapı$\mathrm{m}$, ekipman alımı vb.) dövize endeksli geri ödeme (Dolar-Avro) şeklinde, yıllık faizi \%5-7 aralığında (Libor+Risk primi) olan, ilk iki yılı ödemesiz toplam yedi yıl vadeli ve proje tutarının \%50-75'i kadar destek sağlayan kredi türüdür. Anket formunun ikinci bölümü otel işletmelerinin genel ve finansal durumlarını belirlemeye yönelik sekiz kategorik maddeden oluşmaktadır.

\section{Veri Analiz Teknikleri}

Bu çalışmada, araştırma amacına uygun ve ekonomik olarak verilerin toplanması ve çözümlenebilmesi için gerekli koşulların düzenlenmesi şeklinde açıklanan araştırma modellerinden (Karasar 2005), tarama modeli tercih edilmiştir. Toplanan verilerin analizi SPSS 13.0 ve Lisrel 8.0 istatistik paket programında gerçekleştirilmiştir. Çalışmadaki analizlerin ön koşulları gereği verilere öncelikle sapan analizi, ardından çoklu normal dağılım analizleri yapılarak verilerin normal dağılıma uygun hale gel- 
meleri sağlanmıştır. Normal dağılan verilerin güvenilirlilik testi için güvenilirliğin bir ölçütü olan "Cronbach's Alfa" testi; yapısal geçerlilik testi için açımlayıcı ve doğrulayıcı faktör analizi kullanılmıştır. Çalışmada yararlanılan diğer istatistik yöntemleri ise yüzde ve frekans dağılımları ve bağımlı iki örnek t-testi'dir.

\section{Araştırma Soruları}

Araştırma amacına yönelik olarak iki tane araştırma sorusu belirlenmiştir. Birinci araştırma sorusunun nedeni katılımciların mevcut durumdaki performanslarının yeşil kredi kullanma durumlarında ortaya çıkması muhtemel performanslarından farklılık taşıyıp taşımadığını belirlemektir. Daha önce yapılan çalışmalarda (Revila vd. 2001; Moreno vd. 2004; Tzschentke vd. 2004; Graci ve Dodds 2008) işletmelerin maliyetlerini düşürerek daha rekabetçi olacaklarını, rekabetçilikle motive olan bir işletmenin aktivitelerinden kaynaklı olarak çevresel açıdan olumlu bir itibar kazanacağını ve sonuç olarak toplum gözünde itibarının artacağını düşündükleri ifade edilmiştir. Araştırmanın birinci sorusu ile işletmelerinin yeşil kredi kullanmaları durumunda hangi performans göstergelerinde iyileşme olabileceği belirlenerek, bu finansal aracı otel işletmelerine pazarlamak isteyen bankalar için faydalı bilgiler sağlanması beklenmektedir. Ayrı$\mathrm{ca}$, bu araştırma sorusunun cevaplanması ile henüz yeşil krediyi kullanmamış potansiyel otel işletmeleri için yön gösterici bilgiler elde edilmesi hedeflenmektedir.

Araştırma Sorusu 1: Otellerin mevcut durum performans göstergeleri ile yeşil kredi kullanma durumu performans göstergeleri arasında anlamlı farklilik var mi?

Araştırmanın ikinci sorusu ile işletmelerin performans göstergelerini algıladıkları boyutların, mevcut durum ve yeşil kredi kullanma durumuna göre farklılaşıp farklılaşmadığı araştırılacaktır. Tzschentke vd. (2004), yüzyüze nitel görüşmeler sonucu gerçekleştirdikleri çalışmada, yeşil yönetim stratejilerinin fazla önemli görülmediği işletmelerde sosyal getiri, ekonomik getiri ve maliyet kontrolüne ilişkin değerlendirmelerin ayrı birer faktör olarak ele alındığını; yeşil yönetim stratejilerinin önemli görüldügü işletmelerde ise sosyal faktörlerin de en az ekonomik nedenler kadar önemli güdüler olduğunu ve birlikte bir faktör oluşturduğu- nu, maliyet kontrolü faktörünün ise ayrı bir boyut oluşturduğunu belirlemiştir. Tzschentke vd.'nin (2004) çalışmasından yola çıkılarak oluşturulan araştırmanın ikinci sorusu ile otel işletmelerinin performans göstergelerinin ait olduğu boyutların, mevcut durum ve yeşil kredi kullanma durumuna bağlı olarak farklılık gösterip göstermeyeceği araştırılacaktır.

Araştırma Sorusu 2: Otellerin performans göstergelerinin ait olduğu faktör boyutları "Mevcut Durum" ve "Yeşil Kredi Kullanma Durumuna" göre farklılaşır mı?

\section{VERILERIN ANALIZI VE BULGULAR}

Araştırmanın bu bölümde öncelikle 142 işletmeye ait genel bilgiler anlatılmıştır. Daha sonra araştırma amacı çerçevesinde, otellerin performans göstergelerinin yeşil kredi kullanma durumuna göre farklılaşıp farklılaşmadığı ve performans göstergelerinin ait olduğu boyutların yeşil kredi kullanma durumuna göre farklılaşıp farklılaşmadığına ait bulgular istatistiksel analizler sonucunda ortaya koyulmuştur.

\section{Kategorik Özellikler}

Çalışmaya katılan konaklama işletmelerinin büyük oranının sahil oteli (\%78), mülkiyet sahipliklerinin tek sahipli patron ve ortaklık otelleri (\%40), hukuki yapılarının çoğunlukla anonim şirket (\%76) olduğu görülmüştür. Otel işletmelerinin yatırım sürecinde ağırlıkla özsermaye ve yurtiçi banka kredisi kullandıkları, son 5 yılda otellerine yenileme yatırımı yapan işletmelerinin oldukça yüksek olduğu (\%80) ve bu yenileme yatırımlarını özsermaye (\%52) ve yurtiçi banka kredileri (\%39) kullanarak yaptıkları gözlenmiştir. Ek olarak araştırmaya katılan finans müdürlerinin $\% 86^{\prime}$ s1, otellerinin yeşil otel olmasını önemli bir konu olarak bulduklarını ifade etmektedir.

\section{Güvenilirlik Analizi Sonuçları}

Mevcut durum ve yeşil kredi kullanma duruma göre çalışmaya dahil edilen maddelerin tamamı için güvenilirliğin bir göstergesi olan Cronbach Alfa test değerleri, maddelerin yüksek düzeyde güvenilir olduğunu göstermektedir (Tablo 1). Özdamar'ın (2011) belirttiği üzere $0,70 \leq \alpha<0,90$ aralığındaki bir Alfa değeri, güvenilirliğin olduk- 
ça iyi düzeyde olduğunu göstermektedir. Madde havuzunda güvenilirlik düzeyini bozan herhangi bir madde olmadığı, maddelerin tamamının her iki koşulda da Tukey'in Toplanabilirlik Testine göre toplanabilir özellikte olduğu ( $p>0,05)$, Hotelling's T-kare istatistiği sonucuna göre maddelerin homojen bir yapıda ve çoklu normal dağılımdan geldiği söylenebilir $(p<0,001)$ (Özdamar 2011).

\section{Ölçek Maddelerine İlişkin Betimleyici İstatistikler}

Çalışmaya katılan finans müdürlerinden ilk olarak, otellerinin mevcut durumlarını göz önünde bulundurarak ankette yer alan performans göstergelerini 1=çok kötü, 5=çok iyi olacak şekilde derecelendirmeleri istenmiştir. Daha sonra ise kendilerine sunulan yeşil kredi şartını değerlendirerek, aynı performans göstergelerini yeşil krediyi kullanmaları varsayımına göre tekrar 1'den 5'e kadar derecelendirmeleri istenmiştir. Böylelikle, iki duruma göre işaretlenen anket maddeleri arasındaki puan farklılıklarından katılımcıların yeşil kredilere karşı olumlu ve olumsuz bakış açıları anlaşılabilecektir. Tablo 2'de performans maddelerine ilişkin ortalama oranlar ve standart sapmalar verilmiştir. Maddeler incelendiğinde, performans göstergeleri arasında en yüksek değişimin, "sezonluk yenileme yapabilme gücü” $(3,59$ / 4,23), "sosyal sorumluluk faaliyetleri" $(3,48$ / 4,08), "yeni pazarlara giriş" (3,49 / 4,00), "fiyat rekabet gücü" $(3,58 / 4,06)$, "operatör ve acentalarla pazarlık gücü" $(3,62 / 4,08)$, "elektrik maliyet kontrolü" $(3,61 / 4,04)$ ve "atık maliyet kontrolü" $(3,35$ / 3,98) değişkenlerinde ortaya çıktığ1 görülmektedir.

Katılımcıların yanıtlarından, mevcut performans göstergelerinde "iyi" olarak nitelendirdikleri maddeler için yeşil kredi kullanmayı çok gerekli görmedikleri, "kötü", “orta" ve "çok iyi” olarak nite- lendirilen maddeler içinse yeşil kredi kullanmayı gerekli gördükleri anlaşılmaktadır. Katılımcıların \%84,47'si “yeşil kredi" kullanmaları durumunda performans göstergelerinin iyi ve üzeri olacağını ifade etmiştir. Katılımcıların \%54,93'ü borçları ödeme gücünün, \%50,7'si çevre yasalarına uymasının, \%49,3'ü kurumsal sosyal itibarının, \%47,89'u kurumsal ekonomik itibarlarının ve $\% 40,85^{\prime} i$ ise yenileme yapabilme güçlerinin yeşil kredi kullanmaları durumunda çok iyi olacağını düşünmektedir.

\section{Performans Göstergelerinin Mevcut ve Kredi Kullanma Durumuna Göre Değişimi}

Anketin birinci bölümünde yer alan 16 performans göstergesinin otel işletmelerinin mevcut durumu ile yeşil kredi kullanması durumuna göre istatistiksel açıdan önemli olarak farklılaşıp farklılaşmadiğı, "Bağımlı İki Örnek t-Testi" ile araştırılmıştır. Buna göre "Mevcut Durum Performans" göstergeleri ile "Yeşil Kredi Kullanma Durumunda Performans" göstergeleri toplam ortalama puanları arasındaki farkın istatistiksel olarak anlamlı olduğu görülmektedir $(3,78 / 4,14$ p<0,001, $|\mathrm{t}| \geq t 0,001$, sd, / $|-5,556|>3,357)$. Yapılan analiz sonucunda yalnızca "kurumsal ekonomik itibar" $(4,22$ / 4,33) ve "borçları ödeme gücü" $(4,27 / 4,39)$ performans göstergelerinin, mevcut durum ve yeşil kredi kullanma durumuna göre anlamlı farklılık göstermediği bulunmuştur ( $p \geq 0,05)$. Madde havuzunda yer alan diğer 14 maddenin tümünün, yeşil kredi kullanma lehine önemli düzeyde anlamlı farklılı̆̆a sahip olduğu bulunmuştur ( $p>0,001)$. Bu durumda araştırmanın birinci araştırma sorusuna yönelik, otellerin mevcut durumlarındaki performans ile yeşil kredi kullanma durumlarındaki performans göstergelerinin ortalama puanları arasında ileri düzeyde anlamlı fark bulunduğu söylenebilir. Buna göre çalışmanın birinci araştırma sorusuna yanıt verilerek, performans göstergelerinin 14 tanesinin yeşil kre-

Tablo 1. Ölçek Maddelerine İlişkin Güvenilirlik Analizi Sonuçları

\begin{tabular}{|c|c|c|}
\hline & $\begin{array}{c}\text { Mevcut Durum } \\
\text { Performans Göstergeleri }\end{array}$ & $\begin{array}{r}\text { Yeşil Kredi Kullanma } \\
\text { Durumunda Performans Göstergeleri }\end{array}$ \\
\hline Maddelerin Toplam Cronbach Alfa Değeri & 0,928 & 0,964 \\
\hline Maddelerin ilk yarısı için Cronbach Alfa & 0,852 & 0,924 \\
\hline Maddelerin ikinci yarısı için Cronbach Alfa & 0,899 & 0,943 \\
\hline Maddelerin bütün korelasyon değeri aralığı & $0,520-0,749$ & $0,677-0,844$ \\
\hline
\end{tabular}


Yeşil Bankacılık ve Yeşil Krediler: Antalya'daki 4-5 Yıldızıı Otel İşletmelerinin Bakış Açıları Üzerine Bir Araştırma

Tablo 2. Katılımclların Ölçekte Yer Alan Performans Göstergelerine İlişkin Verdikleri Puanların Betimleyici İstatistikleri (n=142)

\begin{tabular}{|c|c|c|c|c|}
\hline \multirow[b]{2}{*}{ Performans Ifadeleri } & \multicolumn{2}{|c|}{ Mevcut durum performans } & \multicolumn{2}{|c|}{$\begin{array}{c}\text { Yeşil kredi kullanılması durumunda } \\
\text { beklenen performans }\end{array}$} \\
\hline & Ort. & Standart Sapma & Ort. & Standart Sapma \\
\hline Elektrik maliyet kontrolü & 3,61 & ,866 & 4,04 & ,846 \\
\hline Su maliyet kontrolü & 3,64 & ,845 & 3,97 & ,833 \\
\hline Atık maliyet kontrolü & 3,35 & 923 & 3,98 & ,838 \\
\hline Doluluk oranları & 3,95 & ,708 & 4,13 & ,801 \\
\hline Misafir geceleme sayısı & 3,97 & ,714 & 4,17 & ,799 \\
\hline Operatör ve acenteler ile pazarlık gücü & 3,62 & ,920 & 4,08 & ,868 \\
\hline Yeni pazarlara giriş & 3,49 & ,797 & 4,00 & 808 \\
\hline Ürün ve hizmet çeşitliliği & 3,88 & 812 & 4,21 & ,713 \\
\hline Sosyal sorumluluk faaliyetleri & 3,48 & ,873 & 4,08 & ,829 \\
\hline Kurumsal sosyal itibar & 4,13 & ,810 & 4,34 & ,807 \\
\hline Kurumsal ekonomik itibar & 4,22 & ,773 & 4,33 & ,805 \\
\hline Çevre yasalarına uyması & 4,11 & ,800 & 4,35 & ,834 \\
\hline Borçları ödeme gücü & 4,27 & ,816 & 4,39 & ,841 \\
\hline Kârlılık durumu & 3,51 & ,692 & 3,88 & ,821 \\
\hline Fiyat rekabet gücü & 3,58 & ,819 & 4,06 & ,849 \\
\hline Sezonluk yenileme yapabilme gücü & 3,59 &, 755 & 4,23 & ,802 \\
\hline Genel Ortalama & 3,78 &, 560 & 4,14 & ,658 \\
\hline
\end{tabular}

di kullanılması durumunda mevcut duruma göre anlamlı şekilde olumlu yönde değişim gösterdiği anlaşılmaktadır. Maddeler arasındaki farklılıklar Şekil 1'de daha net incelenebilir.

\section{Performans Göstergelerinin Otellerin Mevcut Durumuna Göre Boyutları}

Çalışmanın ikinci araştırma sorusuna yanıt verebilmek için, performans maddelerinin faktör yapıları araştırılmıştır. Bu amaçla gerçekleştirilen faktör analizi sürecinde, temel bileşenler yöntemi ve Ouartimax dönüştürme yöntemi kullanılarak özdeğeri 1'in üzerinde, binişiklik sorunu göstermeyen (maddeler arası yük değer farkları ve faktör yük kabul düzeyi 0,50'nin altında olmayan maddelerden meydana gelen faktör yapıları tercih edilmiştir (Çokluk vd. 2010). Ölçek içerisindeki “Kurumsal ekonomik itibar", "Doluluk oranları" ve "Misafir geceleme sayısı" maddelerinin birden fazla faktör yapısına dağılarak, binişiklik gösterdiği belirlenmiştir. İlgili maddelerin ölçekten çıkarılmasıyla, faktör analizi yenilenmiş, ilk etapta 4 faktör boyutu ile varyansın \%72,665'ini açıklayan maddeler, sorunlu maddelerin ölçekten çıkartılması ile üç faktör yapisında toplanarak, varyansın \%68,606'sinı açıklamıştır (Tablo 3). Analize dâhil edilen değişkenler ile ilgili toplam varyansın 2/3'ü kadar miktarın açıklanması önemli bir açıklayıcılık olarak değerlendirilebilir (Çokluk vd. 2010). Özdeğeri 1'in üzerinde üç alt faktöre ayrılan ölçeğin KMO test istatistiği 0,907, Bartlett küresellik testi sonucu ise istatistiksel olarak anlamlı bulunmuştur $(p<0,001)$. Örneklem hacmi ile veri yapısının uygunluğunu test eden bir ölçüm olan KMO değerinin 0,90> üzeri çıkarak mükemmel uyumda olduğu söylenebilir (Çokluk vd. 2010). Buna göre; "ekonomik performans", "maliyet kontrol performans1" ve "sosyal 


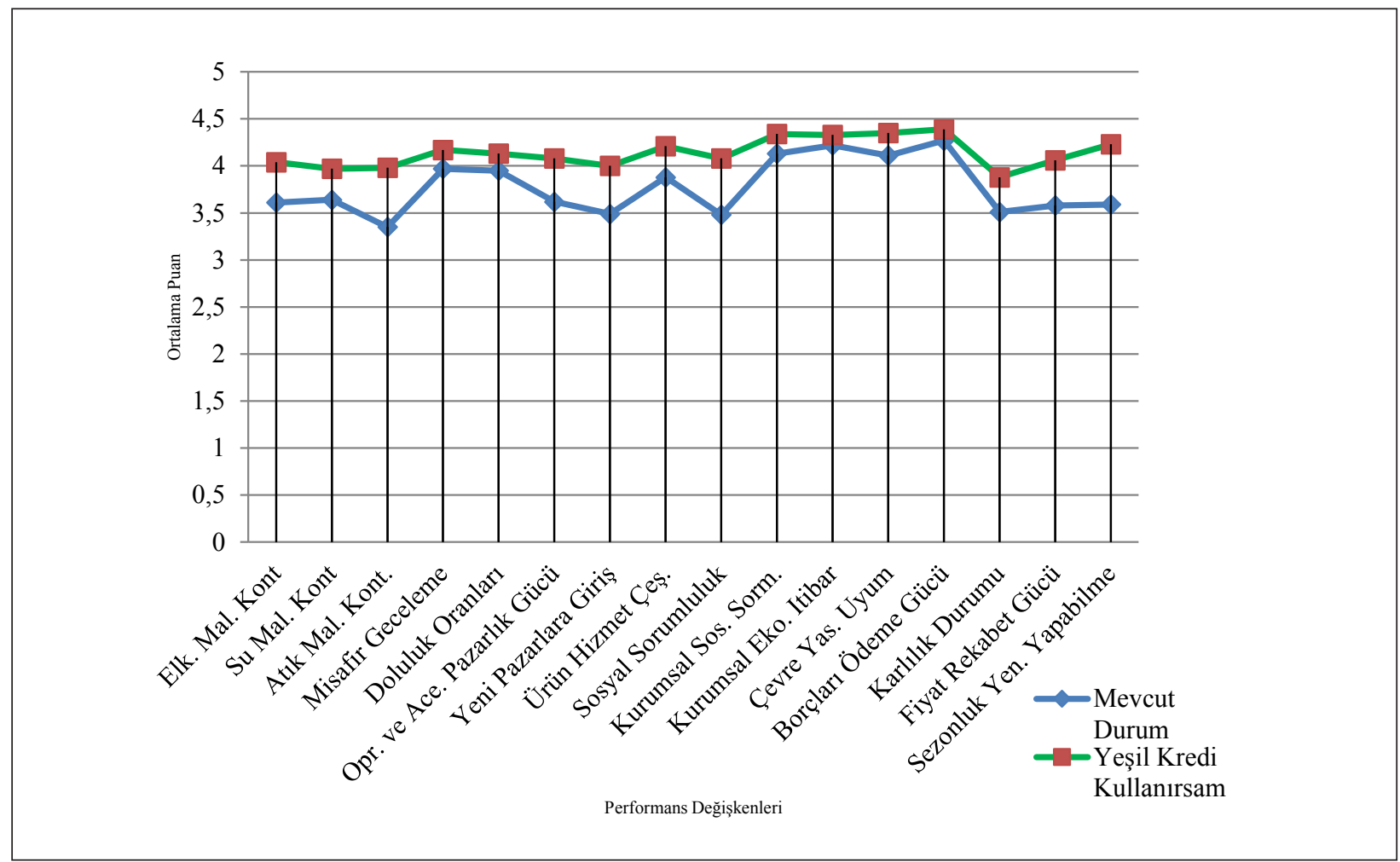

Şekil 1. Mevcut Durum ve Yeşil Kredi Kullanma Durumuna Göre Performans Göstergelerinin Ortalamaları Arasındaki Farklar

performans" alt boyutlarının, otel işletmelerinin mevcut performanslarını açıklayıcı birer alt faktörler olduklarına karar verilmiştir.

Otel işletmelerinin performanslarını ölçmek üzere geliştirilen maddelere, yapısal eşitlik modeli istatistik paket programı kullanılarak, birinci düzey doğrulayıcı faktör analizi (DFA) uygulanmıştır. Doğrulayıcı faktör analizleri, ölçme aracı sonucu elde edilen verilerin, söz konusu olguyu açılamada geçerli yapılar olup olmadığını test eder (Çokluk vd. 2010). Buna göre, otel işletmelerinin performanslarını ölçmeye çalışan ölçeğe, doğrulayıcı faktör analizi uygulanarak, Şekil 2'deki yol analizi diyagramı elde edilmiştir. Modeli incelediğimizde, ekonomik, maliyet ve sosyal performans örtük değişkenlerinin, 13 adet gözlenen değişken tarafından açıklandığı görülmektedir. Buna göre öncelikle modelin uyum iyiliklerinin yorumlanmasindan önce, gözlenen değişkenlere ait kritik t- değeri istatistiklerini incelemek gerekmektedir. 0,05 düzeyinde anlamlılık için kritik t-değeri 1,96 iken, 0.01 düzeyinde anlamlık için 2,576'dır (Jöreskog ve Sörbom 1994'ten aktaran Şimşek 2007: 86). Buna göre gözlenen değişkenlerin t-değerleri 7,11 ile
12,78 arasında bir değişiklik göstermiştir $(\mathrm{p}<0,001)$. Bununla birlikte örtük değişkenler olan "sosyal", "ekonomik" ve "maliyet kontrol" performans boyutlarının arasındaki ilişkinin anlamlılığına yönelik t-değerleri 9,35 ile 17,31 arasında değişiklik göstererek anlamlı bulunmuştur $(\mathrm{p}<0,001)$.

Modelde yer alan gizil değişkenler arası ilişkiye göz atıldığında maliyet kontrolü ile ekonomik performans değişkenleri arasında 0,72'lik, maliyet ile sosyal performans değişkenleri arasında 0,62'lik ve ekonomik performans ile sosyal performans değişkenleri arasında ise 0,80'lik bir ilişki ortaya çıkmaktadır. Modelin en önemli uyum iyiliklerinden iki tanesi Şekil 2'nin altında yer almaktadır. Gözlenen ve beklenen kovaryans matrisi arasında fark yoktur hipotezine dayanan Ki-kare uyum indeksinin örneklem büyüklülüğüne duyarlılığı nedeniyle önerilen Ki-karenin serbestlik derecesine bölünmesiyle elde edilen sonucun 2 veya $2,5^{\prime}$ in altında olması mükemmel uyuma işaret eder (Çokluk vd. 2010). Buna göre 112,06 / $62=1,8074$ sonucu, modelin mükemmel uyuma sahip olduğunu göstermektedir. Diğer bir önemli uyum iyiliği olan, yaklaşık hataların karekökü anlamına gelen RMSEA değe- 
Tablo 3. Mevcut Durum Performans Ölçeği Faktör Analizi Sonuçları

\begin{tabular}{|c|c|c|c|c|c|}
\hline Faktörler & Madde Yükleri & Ort. & Özdeğer & Varyans Açıklama \% & Alfa \\
\hline Faktör 1: Ekonomik Performans (7 madde) & & 3,71 & 5,646 & 43,432 & 0,875 \\
\hline Operatör ve acenteler ile pazarlık gücü & ,815 & & & & \\
\hline Fiyat rekabet gücü & ,796 & & & & \\
\hline Kârlılık durumu &, 787 & & & & \\
\hline Borçları ödeme gücü &, 754 & & & & \\
\hline Yeni pazarlara giriş &, 750 & & & & \\
\hline Ürün ve hizmet çeşitliliği & ,670 & & & & \\
\hline Sezonluk yenileme yapabilmesi &, 657 & & & & \\
\hline Faktör 2: Maliyet Kontrol Performansı (3 madde) & & 3,55 & 1,696 & 13,044 & 0,873 \\
\hline Su maliyet kontrolü &, 758 & & & & \\
\hline Atık maliyet kontrolü &, 684 & & & & \\
\hline Elektrik maliyet kontrolü &, 681 & & & & \\
\hline Faktör 3: Sosyal Performans (3 madde) & & 3,93 & 1,577 & 12,131 & 0,833 \\
\hline Kurumsal sosyal itibar & ,697 & & & & \\
\hline Sosyal sorumluluk faaliyetleri & ,683 & & & & \\
\hline Çevre yasalarına uyum &, 560 & & & & \\
\hline
\end{tabular}

Quartimax rotasyonlu temel bileşenler analizi; Açıklanan toplam varyans=\% 68,606;

Kaiser-Meyer-Olkin örneklem uygunluk ölçümü=, 907; \%90,7

Bartlet'in Küresellik Testi: X2 =1022,967, s.d=78, p<0,001

ri uyum iyiliğinin $\leq 0,5$ olması mükemmel uyu$\mathrm{mu}, 0,06-0,08$ aralığında olması ise modellerin iyi uyuma sahip olduğunu gösterir (Çokluk vd. 2010). Ölçeğin RMSEA uyum iyiliğinin, 0,076 olması yine ölçeğin iyi derecede uyuma sahip olduğunu göstermektedir. Ölçeğe ait diğer uyum iyilikleri (GFI $=0,90, \mathrm{RMR}=0,035, \mathrm{SRMR}=0,053, \mathrm{NFI}=0,95 \mathrm{VE}$ NNFI $=0,97$ ) kriter kabul noktalarını karşılayarak iyi derecede uyumu işaret etmektedir (Çokluk vd. 2010: 271).

\section{Performans Göstergelerinin Otellerin Yeşil Krediden Bekledikleri Faydaya Göre Boyutları}

Parasuraman vd. (1985) hizmet kalitesinin kavramsallaştırılması üzerine gerçekleştirdikleri çalışmalarında tüketicilerin kalite algısının beklenen hizmet ve karşılaşılan hizmet arasındaki farkın sonucunda oluştuğunu ifade etmektedir. Buna göre beklentinin karşılaşılan hizmet performansından büyük olmasının memnuniyetsizlik, aksi durumun ise memnuniyet yaratacağ $\breve{g}_{1}$ ifade edilmektedir. $\mathrm{Bu}$ çalışmadan esinlenerek, finans yöneticilerinin çalışmada önerilen yeşil krediden bekledikleri faydayı, güncel performanslarını göz önünde tutarak değerlendirecekleri varsayılmıştır. Ankette yer alan performans göstergelerinde güçlü olduğunu düşünen bir yöneticinin yeşil kredi kullanma gerekliliğinin düşük, buna karşın performans göstergelerinde zayıf olduğunu düşünen yöneticinin ise yeşil kredi kullanma gerekliliğinin daha yüksek olabileceği söylenebilir. Böylelikle yeşil kredi kullanmadan kaynaklı gerçekleşecek performansın lehine pozitif farklar krediye yönelik olumlu bakış açısını, negatif farklar ise olumsuz bakış açısını göstermektedir. Bunun dişında genel bir ifadeyle, "Verdiğim bu bilgiler 1şığında bende görüş sunmam istense bu kredinin alınmasını üst yönetime" 1=Kesinlikle önermem'den $5=$ Kesinlikle öneririm'e kadar değişen tepki kategorileriyle yöneltilen soruya, finans yöneticilerinin \% 67'si öneririm yanıtı vermiştir.

Analizleri gerçekleştirebilmek için kredi kullanımından beklenen performanstan, mevcut performans puanlarının çıkarılmasıyla, aynı ölçek maddeleri üzerinden 9'lu Likert Tipi bir ölçek geliştirilmiştir. Beklentiden, mevcut performansın çıkarılmasıyla elde edilen ölçeğin $-4 /+4$ aralığında değişmesinden ötürü, ölçeğin tepki kategorileri yeniden düzenlenerek, -4 ' puanının 1 puan, $+4^{\prime}$ ün 9 puan olacak şekilde tüm aralıklar yeniden kodlanmıştır. Likert tipi ölçeğin tepki kategorileri, $1=$ Çok olumsuz değişir' den, 9=Çok olumlu değişir' şeklinde 


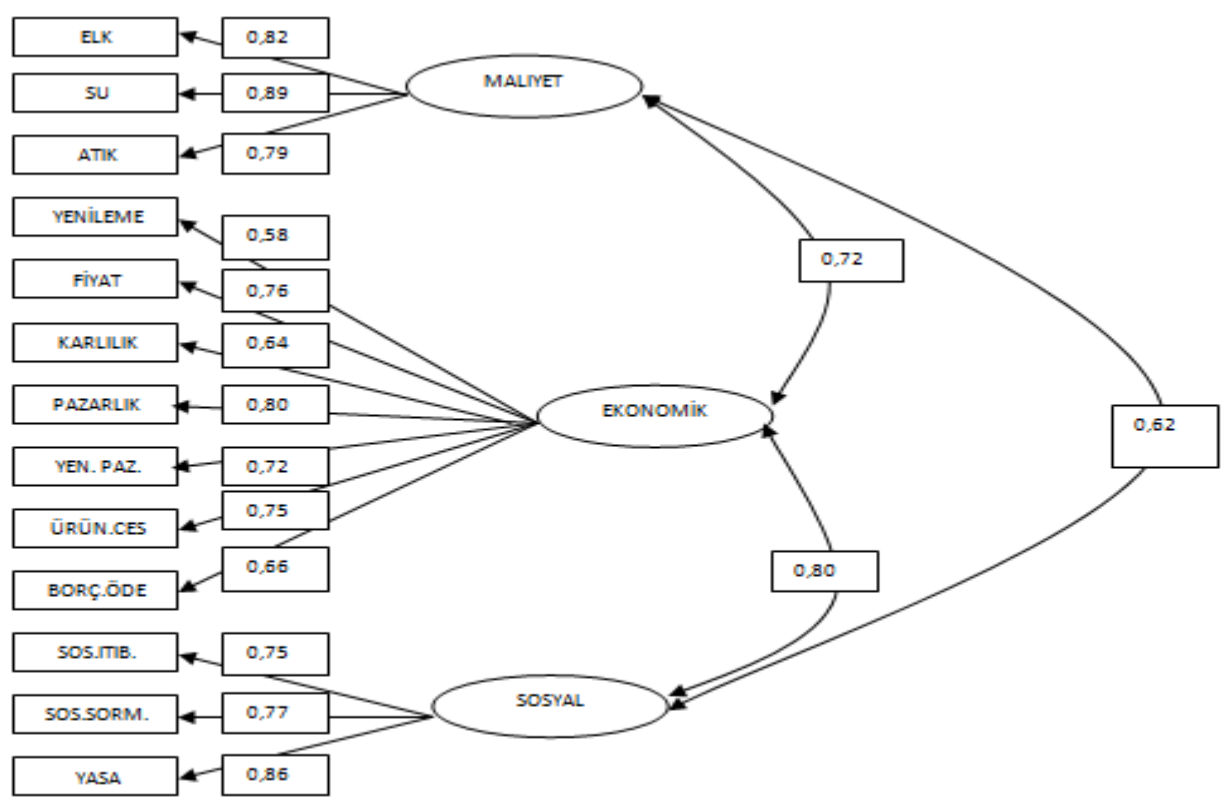

Şekil 2. Mevcut Performans Ölçeği DFA Yol Diyagramı

yeniden oluşturulmuştur. Böylelikle işletmelerin yeşil kredi kullanmadan kaynaklı memnuniyet dereceleri ortaya koyulmuştur. Verilerin tekrar düzenlenmesi ile oluşturulan bu bölüm, otellerin yeşil kredi kullanmaları durumunda performans göstergelerinde ne yönde bir değişim olacağını anlamaya ve bu performans göstergelerinin hangi faktör yapıları altında toplanacağını açıklamaya yardımcı olacaktır. Dolayısıyla, bu maddelere faktör analizi uygulanarak, performans göstergelerinin yeşil kredi kullanılması durumunda hangi boyutlar altında yer alacağı ortaya koyulmuştur. Temel bileşenler yöntemi ve Ouartimax dönüştürme yöntemi kullanılarak özdeğeri 1'in üzerinde, binişiklik sorunu göstermeyen ve faktör yük kabul düzeyi 0,50'nin altında olmayan maddelerden meydana gelen faktörler yapıları tercih edilmiştir. Sapan değerlerinin analizi ve çok değişkenli normal dağılım analizleri sırasında 5 adet katılımcının cevaplarının sapan veri bulunarak ölçekten çıkarılmasıyla faktör analizine 137 veri ile girilmiştir.

Faktör analizi sonuçlarına geçmeden önce güvenilirlik analizi yapılan performans göstergelerinin Cronbach alfa istatistiği 0,951 bulunmuş, maddelerin toplam güvenilirliğini bozan herhangi bir maddeye rastlanmamış, maddelerin tümü bir bütün olarak toplanabilir bulunmuş $(p>0,05)$ ve Hotelling's T-kare istatistiği anlamlı bulunmuştur $(p<0,001)$. Yeşil kredi kullanma durumundaki performans - mevcut performans formülünü işleterek ortaya çıkan sonuçlardan elde edilen performans göstergelerinin, iki faktörlü bir yapıda açıkland1ğ1 görülmektedir. Buna göre birinci faktör yapısı, daha önce mevcut durum performansı analizinde iki farklı faktör yapısına ayrılan "ekonomik performans ve sosyal performans" faktörlerinin bir araya gelmesinden oluşmaktadır. Toplam varyansın \%41,61'ini açıklayan bu faktör yapısının ortalama puanı 5,44'dür. Faktör analizi sonucunda ortaya çkan bir diğer performans boyutu ise "maliyet performans" boyutudur. Toplam açıklanan varyansın, $\% 24,76$ 'sını açıklayan "maliyet performansı" faktörünün ortalama puanı ise 5,51 olarak bulunmuştur. İki faktör yapısı toplamda \%66,380 varyans açılamıştır. Faktör analizine ilişkin istatistikler Tablo 4 'te verilmiştir.

Faktör analizi sonuçlarına göre performans gözlenen değişkenlerinin, katılımcılar tarafından hangi örtük yapılar altında algılandığı belirlenmiştir. Doğrulayıcı faktör analizi sonucunda Şekil 3'deki yol analizi diyagramı elde edilmiştir. Yapılan t-değeri kontrolleri sonucunda tüm değişkenlerin 
Tablo 4. Yeşil Kredilerin Algılanan Faydasını Açıklayan Ölçeğin Faktör Analizi Sonuçları

\begin{tabular}{|c|c|c|c|c|c|}
\hline Faktörler & Madde Yükleri & Ort. & Özdeğer & Varyans Açıklama \% & Alfa \\
\hline Faktör 1: Sosyal ve Ekonomik Performans (10 madde) & & 5,44 & 5,410 & 41,61 & 0,931 \\
\hline Borçları ödeme gücü & ,796 & & & & \\
\hline Kurumsal sosyal itibar & ,788 & & & & \\
\hline Ürün ve hizmet çeşitliliği & ,756 & & & & \\
\hline Operatör ve acenteler ile pazarlık gücü & ,732 & & & & \\
\hline Fiyat rekabet gücü & ,724 & & & & \\
\hline Kârlılık durumu & ,698 & & & & \\
\hline Sezonluk yenileme yapabilmesi & ,670 & & & & \\
\hline Yeni pazarlara giriş & ,663 & & & & \\
\hline Çevre yasalarına uyum & ,642 & & & & \\
\hline Sosyal sorumluluk faaliyetleri & ,636 & & & & \\
\hline Faktör 2: Maliyet Kontrol Performansı (3 madde) & & 5,51 & 3,220 & 24.76 & 0,864 \\
\hline Su maliyet kontrolü & ,863 & & & & \\
\hline Atık maliyet kontrolü & ,857 & & & & \\
\hline Elektrik maliyet kontrolü & ,734 & & & & \\
\hline
\end{tabular}

Quartimax rotasyonlu temel bileşenler analizi; Açıklanan toplam varyans $=\%$ 66,380;

Kaiser-Meyer-Olkin örneklem uygunluk ölçümü=,932;

Bartlet'in Küresellik Testi: X2 =1181,954, s.d= 78, p<0,001

t-değerlerin 8,66 ve 12,35 aralığında değiştiği ve $\mathrm{p}<0,01$ düzeyinde anlamlı olduğu bulunmuştur. Modelde yer alan gizil değişkenler arası ilişkiye göz atıldığında, maliyet kontrolü ile sosyal ve ekonomik performans değişkenleri arasında $0,76^{\prime} l \mathrm{lk}$ bir ilişki olduğu görülmektedir.

DFA analizi yapılan ölçeğin en önemli uyum iyiliklerinden iki tanesi Şekil 3'ün altında görülmektedir. Buna göre 110,27 / $64=1,7229$ Ki-kare uyum iyiliği istatistiği modelin mükemmel uyuma sahip olduğunu göstermektedir. Diğer bir önemli uyum iyiliği olan, RMSEA uyum iyiliğinin 0,07 olması yine ölçeğin iyi derecede uyuma sahip olduğunu göstermektedir. Ölçeğe ait diğer uyum iyilikleri (GFI $=0,90$, RMR $=0,048$, SRMR $=0,048$, NFI $=0,96$ VE NNFI $=0,98$ ) kriter kabul noktalarını karşılayarak iyi derecede uyumu işaret etmektedir (Çokluk vd. 2010: 271).

$\mathrm{Bu}$ bulgular neticesinde araştırmanın ikinci sorusuna yanıt verilmiştir. Buna göre "Otellerin performans göstergelerinin ait olduğu faktör yapıları "mevcut durum" ve "yeşil kredi kullanma durumuna" göre farklılaşır mı?" sorusunun yanıtını bulabilmek için açımlayıcı ve doğrulayıcı faktör analizleri gerçekleştirilmiştir. Faktör analizleri sonucunda otellerin performans göstergelerinin mevcut durumuna ilişkin faktör analizi "ekono- mik", "sosyal" ve "maliyet kontrol" "olarak üç faktör yapısında algılanmıştır. Ekonomik performans boyutunun en yüksek açıklayıcılığa sahip olduğu faktör analizi sonuçlarına göre, "maliyet kontrol" ve "sosyal" performans boyutları birbirilerine yakın oranda açıklayıcılığa sahip olarak, üç faktör toplam varyansın yaklaşık \%69'unu açıklamıştır. Buna karşılık, otellerin mevcut performans göstergeleri puanlarının, yeşil kredi kullanma durumundaki performans göstergelerinden çıartılması ile elde edilen "yeşil kredilerden algılanan faydayı" gösteren performans ölçeği ise katılımcılar tarafından iki boyutta, "sosyal ve ekonomik" ve "maliyet kontrol" performans boyutları şeklinde algılanmıştır. "Sosyal ve ekonomik" faktör boyutunun öncül açıklayıcı olarak bulunduğu analiz sonucunda iki faktör toplam varyansın yaklaşık \%67'sini açıklamiştır.

İki ölçeğin birbirinden farklı boyutlara sahip olmasından ötürü, dahası yeşil kredi kullanma durumunda faktör boyutlarının gerek sayısının gerekse içeriğinin değişmesi, faktör ortalamaları arasında anlamlı bir farkı test etmeyi mümkün kılmamaktadır. Aynı performans göstergelerine sahip iki ölçeğin yeşil kredi kullanma durumu söz konusu olduğunda farklı faktör yapılarına ayrıldığı görülmektedir. Mevcut durum performanslarında sosyal 


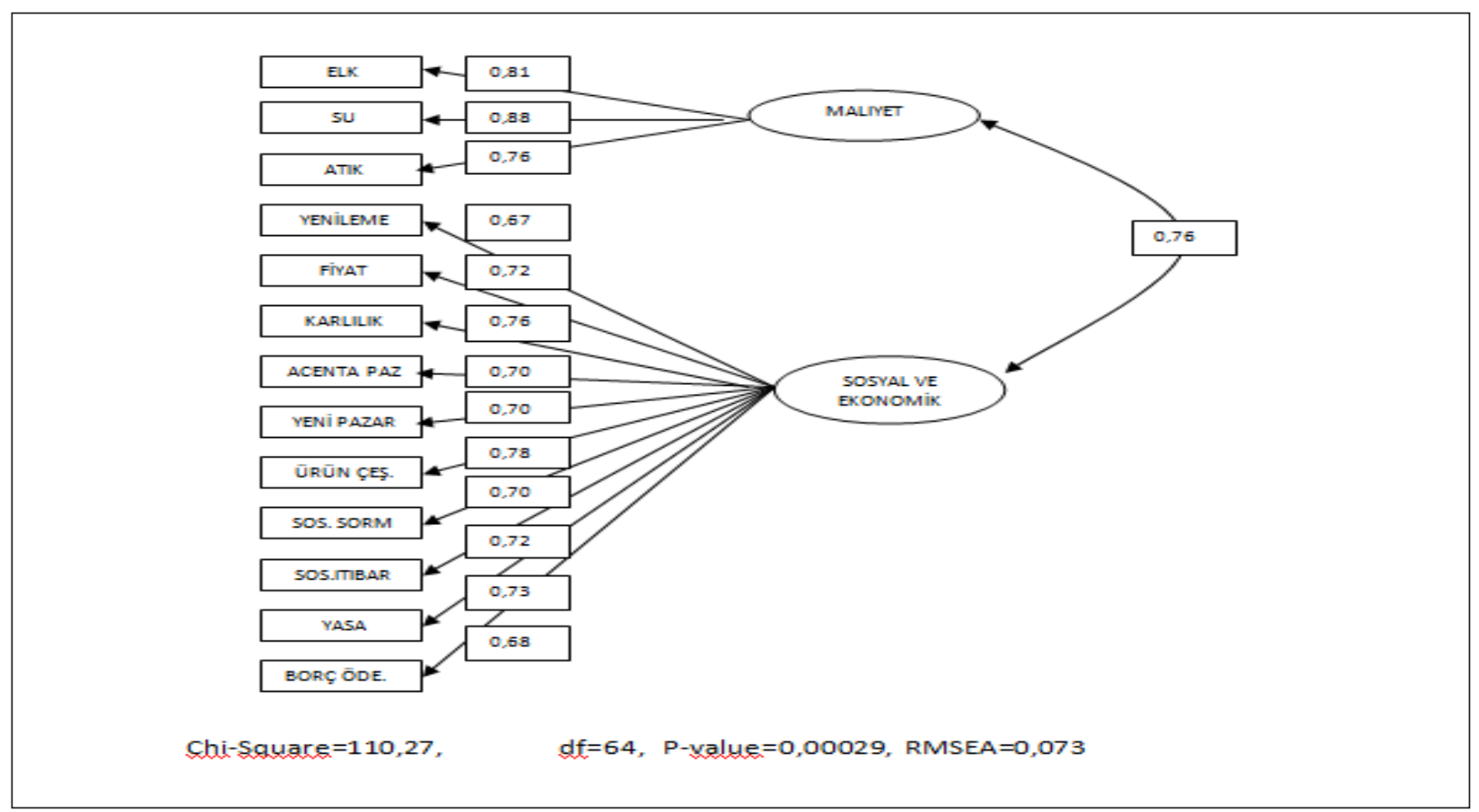

Şekil 3. Otellerin Yeşil Kredi Kullanma Nedenlerini Açıklayan Ölçeğin DFA Yol Diyagramı

performans göstergelerinin tek başına bir faktör olarak algılandığı, ancak aynı faktörün yeşil kredi kullanılması durumunda "ekonomik" performans boyutuyla birlikte yer alması oldukça dikkat çekicidir. Yeşil kredi kullanmadan önce performans göstergelerini üç faktörde algılayan katılımcılar, yeşil kredi kullanmaları durumunda benzer performans göstergelerini iki boyutta algılamıştır. Diğer bir deyişle, yeşil kredi kullanmadan beklenen fayda söz konusu olduğunda, otellerin sosyal performans beklentilerini ekonomik beklentiler ile aynı grupta algıladığı söylenebilir.

\section{SONUÇ VE DEĞERLENDIRME}

\section{Kuramsal Çıktılar}

Araştırmaya katılan finans müdürleri değerlendirdikleri performans göstergelerinin yeşil kredi kullanma durumunda, mevcut durumlarına göre daha olumlu yönde gelişeceğini belirtmişlerdir $(3,78 / 4,14)$. Yeşil kredi kullanmanın işletmelerin finansal göstergelerine olası etkilerine bakıldığında katılımcıların yeşil kredi kullanma durumunda kârlılık durumu $(3,51 / 3,88)$ ve fiyat rekabet gücü $(3,58 / 4,06)$ göstergelerinde gelişme olacağını, bu- na karşın "kurumsal ekonomik itibar" $(4,22$ / 4,33) ve "borçları ödeme gücü" $(4,27 / 4,39)$ göstergelerinde istatistiksel olarak anlamlı bir farklılık oluşmayacağını düşündükleri ortaya çıkmıştır $(p \geq 0,05)$. Hooks (2003) çalışmasında yüksek miktarda kredi çekilmesinin büyük işletmeler açısından sorun olabileceğini belirtmiştir. Her ne kadar mevcut duruma göre önemli bir farklılık içermese dahi yeşil kredilerin kullanılmasında böyle bir sıkıntı görülmediği ortadadır. Benzer şekilde yeşil kredilerin finansal etkileri Agarwal ve Eltson (2001) ve Yao ve Ouyang'ın (2007) çalışmalarının aksine borçları ödeme gücü dışında kârlılık ve fiyat rekabeti elde etme bağlaminda geleneksel kredilerden ayrıldığ 1 görülmektedir. Bu sonuç, Krivogorsky vd. (2009) ve Shen ve Wang'ın (2005) bulguladığı geleneksel kredilerin getirileri ile benzerlik göstermektedir. Graci ve Dodds'un (2008) Kanada'daki otel işletmelerinin yeşile yönelmesine etki eden unsurları araştırdıkları çalışmalarında, işletmelerin yeşile yönelmesinden temel beklentilerin, maliyetlerin düşürülmesi ile daha rekabetçi bir işletme olunmas1 ve bu yolla toplum gözünde itibarının artması olarak ifade edilmiştir. Revila vd. (2001) önceki çalışmalar ile benzer olarak yedi otel üzerinde yapt1- 
ğ 1 araştırmasında, otellerin yeşil yönetimle en çok rekabet edebilirlik güçlerinin artmasını beklediklerini belirtmiştir. Diğer bir taraftan, Moreno vd.'nin (2004) 268 otel işletmelerinde yaptığı araştırmada çevresel yönetim anlayışının çevresel performans ile ilişkili olduğu, ancak ekonomik performans ile doğrudan ilişkili olmayabileceğini göstermektedir. Benzer şekilde, Tzschentke vd.'nin (2004) 30 otel müdürü ile yüz yüze gerçekleștirdiği nitel görüşme sonuçlarına göre, görüşülen küçük bir kesim, maliyetten kaynaklı faydaları net olarak izleyememelerinden dolayı, yeşil odaklı davranışlarının temelinde sosyal güdülerin olduğunu belirtmiştir.

Çalışmada ortaya çıkan bir diğer bulgu yeşil kredi kullanma durumunda, performans göstergelerinin ait olduğu boyutların değişmesidir. Yeşil kredi kullanmadan önce performans göstergelerini üç boyutta algılayan finans müdürleri, aynı göstergeleri yeşil kredi kullanma durumunda iki boyutta algılamışlardır. Faktör analizi incelendiğinde, mevcut durum performansında tek başına bir faktör olarak ayrılan sosyal performans göstergelerinin, yeşil kredi kullanıldığı düşünülen durumda, ekonomik performans göstergeleri ile biraraya geldiği anlaşılmıştır. Moreno vd. (2004) ve Tzschentke vd.'nin (2004) nitel gözleme dayalı çalışma sonuçları iki farklı faktör analizi sonuçlarını doğrular niteliktedir. Her iki çalışma da otel müdürlerinin yanıtları doğrultusunda yeşil yönetim anlayışına sahip işletmelerde, sosyal beklentilerin de en az ekonomik beklentiler kadar önemli güdüler olduğunu, işletmelerin sosyal boyutlu endişelerinin, ekonomik beklentilerle paralel beklentiler olduğunu buna karşın maliyet faktörünün işletmeler için zaten olmazsa olmaz olarak tek bir boyut olduğunu ifade etmiştir. Yazarlar ayrıca, işletmelerin maliyetlerini kontrol etmelerinin halkla ilişkiler ve reklam bütçelerine daha fazla kaynak ayırmalarını sağlayacak itici bir unsur olduğu belirtmiştir. Sonuç olarak, yeşil krediler, kendisinden beklenen sosyal performans göstergeleri sebebiyle salt ekonomik beklenti temelli geleneksel kredilerden açık bir şekilde farklılaşmaktadır. Çalışmanın alanyazına bu noktada katkı sunması beklenmektedir. Ayrıca işletmelerin yeşil yatırım yapmalarından bekledikleri performans göstergelerine ilişkin geliştirilen ölçeğin iyi derecede güvenilirlik ve uyum istatistiklerine sahip olması, bundan sonra yapılabilecek çeşitli araştırmalar için alanyazına kullanılabilir bir ölçek sunmaktadır.

\section{Uygulamaya Yönelik Çıktılar}

Duran varlık maliyetlerinin büyüklügü sebebiyle yatırım harcamalarının çok yüksek olması otelleri kredi kullanımına yöneltirken, göreceli olarak daha düşük tutardaki yenileme-modernizasyon yatırımları için otellerin daha çok özsermayelerini (\%52) kullandıkları anlaşılmaktadır. Buna karşın, araştırmaya katılan otellerin \% 39'unun yenileme yatırımları için dahi yurtiçi banka kredileri kullandıklarını belirtmeleri, yeşil yatırımların yeşil krediler için uygun bir pazar olabileceğini göstermektedir. Araştırmaya katılan finans müdürlerinin yeşil otel olmayı önemli bir unsur olarak buldukları da hesaba katıldığında, otellerin yenileme yatırımları yapabilmeleri için başvurdukları yurtiçi banka kredilerinin, bankacılık sektörü tarafından yeşillenen oteller ya da çevre dostu turizm kredisi gibi isimler ile turizm endüstrisine servis edilmesi faydalı olacaktır. Kredi kullandırma koşullarını çevreci faaliyetlerin yerine getirilmesi taahhüdü ile uygun faiz ve vadelerde kullandıracak bankalar için bu uygulama bir anlamda sosyal sorumluluk faaliyeti olarak değerlendirilebilir.

Çalışmaya katılan finans müdürleri maliyetleri düşürerek otellerini daha rekabetçi yapan performans göstergelerinde ve otellerin toplum gözünde itibarını yükseltecek performans göstergelerinde yeşil kredi kullanmanın anlamlı ve önemli değişimlere yol açacağını düşünürken, "kurumsal ekonomik itibar" ve "borçları ödeme gücü" göstergelerinde anlamlı ve önemli bir değişim olmayacağını düşünmektedirler. Dolayısıyla yöneticilerin yeşil kredi kullanımından beklenen faydayı değerlendirmeleri durumunda, kısa vadeli gelir getirici beklentilerden ziyade uzun vadeli ve dolaylı gelir getirici beklentiler içinde olmaları rasyonellik açısindan uygun olacaktır.

Komple yeni yatırım ya da yenileme yatırımı için kaynak arayışında olan konaklama işletmeleri, bankaların aracılık ettiği, çevre dostu ismiyle de adlandırılan yeşil fon kaynaklarını daha dikkatli inceleyerek, diğer fon kaynakları ile karşılaştırabilir. Çalışmaya katılan finans yöneticilerinin algılamaları, kaynak arayan yatırımcılar için yönlendirici olabilir. Çalışmanın bir diğer uygulamaya yönelik çıtısı da bankacılık sektörüne yöneliktir. Otel finans müdürlerinin yeşil kredi kullanma durumunda performans göstergelerindeki "sosyal ve ekonomik" boyutları bir algılamaları, bankaların 
kredi tutundurma faaliyetleri açısından oldukça önemlidir. Sosyal performans göstergelerinin neden ekonomik performans göstergelerinin yanına gittiğinin anlaşılması, gerek yatırımcılar gerekse yatırımlara fon sağlayanlar açısından önemli bir unsurdur. Buna göre bankalar konaklama işletmelerine yeşil kredi tutundurma çabalarında işletmelerin elde edecekleri getirileri yalnızca "maliyet kontrolü" boyutuyla değil, sağlayacağı pazarlama ve sosyal itibar boyutlarıyla da vurgulamalıdır.

Antalya şehrinde yapılan bu araştırmaya katılan finans müdürlerinin $\% 67$ 'sinin yeşil kredileri getiri ve bedelleri göz önüne alındığında otellere avantaj sağlayacak bir finansal kaynak olarak algıladıkları görülmektedir. Çeşitli niteliklerdeki performans göstergelerinin yeşil kredi kullanımında anlamlı olarak daha olumlu değişeceğini düşünen finans müdürlerinin aynı doğrultuda yeşil krediyi üst yönetime önerilebilir bir kredi olarak görmeleri, bankacılık sektörü adına önemli işaretler taşımaktadır. Bankalar, yeşil krediyi üst yönetimlere önermeye niyeti yüksek olduğu anlaşılan sahil şeridi otelleri için tutundurma faaliyetleri geliştirebilirler.

\section{Sınırlılıklar}

Her araştırmada olduğu gibi bu çalışmanın da bir dizi sınırlılıkları vardır. İlk olarak, alanyazındaki çalışmalardan geliştirilen performans ölçeğine, müşteri memnuniyeti, çalışan tatmini, yasal sorumluluklar ve risk yönetimi gibi diğer performans göstergeleri dâhil edilmemiştir. İkinci sınırlılık anket içerisinde katılımcılara sunulan banka kredisinin, nitelikleri itibariyle tek bir kredi türünü temsil etmesidir. Dolayısıyla katılımcılar tarafından değerlendirilmesi istenen performans göstergeleri, katılımcıların alternatif kredilerin performans göstergelerinde yol açabileceği değişimleri göz önünde tutmaksızın veri sağlamalarına yol açmıştır. Bunun dişında araştırmaya dâhil olan işletmelerin hali hazırda ödemeleri gereken kredilerin bulunması, çalışma içerisinde önerilen krediye bakış açısını olumsuz yönde etkileyebilecek bir sinırlılıktır. Çalışmanın bir diğer sınırlılığı ise 4 yıldızın altındaki otel işletmelerinde finans müdürü unvanına sahip çalışanların çoğunlukla bulunmaması, bu nedenle de bir krediyi değerlendirme yetkisi olmayan kişilerden bilgi toplanmasına engel olmak amaciyla alan araştırmasının yalnızca 4 ve 5 yıldızlı otel işletmeleri ile sınırlı tutulmuş olmasıdır.

\section{KAYNAKÇA}

Aaboen L., Lindelöf, P., Koch. V.C. ve Löfsten, H. (2006). Corporate Governance and Performance of Small High-Tech Firms in Sweden, Technovation, 26: 955-968.

Agarwal, R. ve Elston, J. A. (2001). Bank-Firm Relationships, Financing and Firm Performance in Germany, Economics Letters, 72: 225-232.

Aizawa, M. ve Yang, C. (2010). Green Credit, Green Stimulus, Green Revolution? China's Mobilization of Banks for Environmental Cleanup, Journal of Environment and Development, 19: 119-144.

Akgüç, Ö. (1998). Finansal Yönetim. İstanbul: Avcıol Basım Yayın.

Akış, S. (1999). Sürdürülebilir Turizm ve Türkiye, Anatolia Turizm Araştırmaları Dergisi, 10: 36-46.

Berns, M., Townend, A., Khayat, Z., Balagopal, B., Reeves, M., Hopkins, M. ve Kruschwitz, N. (2009). The Business Of Sustainability: What It Means to Managers Now, MIT Sloan Management Review, 51-1: 6-20.

Bouma, J. J., Jeucken, M. ve Klinkers, L. (2001). Sustainable Banking: The Greening of Finance. Sheffield. Greenleaf Publishing and Deloitte\&Touche.

Campello, M. (2006). Debt Financing: Does it Boost or Hurt Firm Performance in Product Markets?, Journal of Financial Economics, 82: 135-172.

Ceylan, A. ve Korkmaz, T. (2008). Finansal Yönetim. Bursa: Ekin Yayınevi.

Cowton, C. J. ve Thompson P. (2000). Do Codes Make a Difference? The Case of Bank Lending and The Environment, Journal of Business Ethics, 24: 165-178.

Çokluk, Ö., Şekercioğlu, G. ve Büyüköztürk, Ş. (2010). Sosyal Bilimler İçin Çok Değişkenli Istatistik - Spss ve Lisrel Uygulamaları. Ankara: Pegem Akademi.

Faulk, S. (2000). A Survey of Environmental Management by Hotels And Related Tourism Business. Prensentation Paper for Oikos PhD Summer Academy.

Ferri, G. ve Messori, M. (2000). Bank-Firm Relationships and Allocative Efficiency in Northeastern and Central Italy and in the South, Journal of Banking \& Finance, 24: 1067-1095.

Forsyth, T. (1997). Environmental Responsibility and Business Regulation: The Case of Sustainable Tourism, Geographical Journal, 163: 270-280.

Garrod, B. ve Fyall, A. (1998). Beyond the Rhetoric of Sustainable Tourism?, Tourism Management, 19: 199-212.

Graci, S. ve Dodds, R. (2008). Why Go Green? The Business Case for Environmental Commitment in the Canadian Hotel Industry, Anatolia: An International Journal of Tourism and Hospitality Research, 19: 251-270.

Haralambopoulos, D. A. ve Polatidis, H. (2003). Renewable Energy Projects: Structuring a Multicriteria Group Decision-Making Framework, Renewable Energy, 28: 961-973.

Heinkel, R., Kraus, A. ve Zechner, J. (2001). The Effect of Green Investment on Corporate Behavior, The Journal of Financial and Quantitative Analysis, 36-4: 431-449.

Hooks, M. L. (2003), The Impact of Firm Size on Bank Debt Use, Review of Financial Economics, 12: 173-189.

İslamoğlu, H. (2009). Sosyal Bilimlerde Araştırma Yöntemleri. İzmit: Beta Yayınevi. 
Kassinis, G. I. ve Soteriou, A. C. (2003). Greening the Service Profit Chain. The Impact of Environmental, Management Practices, Production and Operations Management, 12: 386-403.

Karasar, N. (2005). Bilimsel Araştırma Yöntemi. Ankara: Nobel Yayın Dağıtım.

Krivogorsky V., Grudnitski, G. ve Dick, W. (2009). Bank Debt and Performance of Continental European Firms, http:// ssrn.com/abstract=1209022. Erişim tarihi: 15 Mart 2014.

Kurt, H. (2009). Finansal Kurumlar İçin Çevre ve Sürdürülebilir Bankacilık, Bankacilar Dergisi, 70: 70-80.

Kuş, E. (2009). Nicel-Nitel Araștırma Teknikleri. Sosyal Bilimlerde Araştırma Teknikleri, Nicel mi? Nitel mi.? Ankara: Anı Yayincilik.

Lee, J. S., Hsu, L. T., Han, H. ve Kim, Y. (2010). Understanding How Consumers View Green Hotels: How a Hotel's Green Image Can Influence Behavioural Intentions, Journal of Sustainable Tourism, 18: 901-904.

Modinos, M. (2000). Sustainability and Regional Development: The Case of the Tourism Sector in Southern Europe, Global Nest: The Int. Journal, 2-3: 301-310.

Moreno, C. E., Lorento, C. J. ve Jimenez, D. B. (2004). Environmental Strategies in Spanish Hotels: Contextual Factors and Performance, The Service Industries Journal, 24: 101-130.

Ogawa, K., Sterken, E., ve Tokutsu, I. (2007). Why do Japanese Firms Prefer Multiple Bank Relationship? Some Evidence From Firm-Level Data, Economic Systems, 31: 49-70.

Özdamar, K. (2011). Paket Programlar ile İstatistiksel Veri Analizi. Eskişehir: Kaan Kitabevi.

Parasuraman, A., Zeithalm, V. A. ve Berry, L. L. (1985). A Conceptual Model of Service Quality and Its Implications for Future Research, Journal of Marketing, 49-4: 41-50.

Penny, W. Y. K. (2007), The Use of Environmental Management As A Facilities Management Tool in The Macao Hotel Sector, Facilities Review, 25: 286-295.

Phillips, P. P. ve Phillips, J. J. (2011). Şirketler İçin Yeşil Karne, Sürdürülebilir Girișimlerde Yatırım Getirisi Nasıl Ölçülür? İstanbul: Soyak Holding.

Revilla, G., Dodd, H. T., ve Hoover, C. L. (2001). Environmental Tactics Used by Hotel Companies in Mexico, International Journal of Hospitality \& Tourism Administration, 3: 111-127.
Sahoo, P. ve Nayak, B. P. (2008). Green Banking in India, Indian Economic Journal, 1: 1-22.

Scholtens, B. (2006). Finance As a Driver of Corporate Social Responsibility, Journal of Business Ethics, 68: 19-33.

Shen, H. C. ve Wang, A. C. (2005). Does Bank Relationship Matter for a Firm's Investment and Financial Constraints? The Case of Taiwan, Pacific-Basin Finance Journal, 13: 163-184.

Sullivan, N. ve O'Dwyer, B. (2009). Stakeholder Perspectives on a Financial Sector Legitimation Process: The Case of NGOs and the Equator Principles, Accounting, Auditing \& Accountability Journal, 22: 553-587.

Swarbrooke, J. (1999). Sustainable Tourism Management. New York: CABI Yayınları.

Şimşek, Ö. F. (2007). Yapısal Eşitlik Modellemesine Giriş, Temel Ilkeler ve Lisrel Uygulamaları. Ankara: Ekinoks.

Thompson, P. (1998). Assesing the Environmental Risk Exposure of UK Banks, International Journal of Bank Marketing, 16: $129-139$

Tzschentke, N., Kirk, D., ve Lynch, P. A. (2004). Reasons for Going Green in Service Accommodation Establishments, International Journal of Contemporary Hospitality Management, 16: 116-124.

IFC (Uluslararası Finans Kuruluşu) (2007). "Sustainability" wwww.ifc.org, Erişim tarihi: 12 Şubat 2012.

Usta, Ö. (2005). İşletme Finansı ve Finansal Yönetim. Ankara: Detay Yayıncilik.

Usta, Ö. (2008). Turizm, Genel ve Yapısal Yaklaşım. Ankara: Detay Yayıncilik.

Weber, O. (2005). Sustainability Benchmarking of European Banks and Financial Service Organizations, Corporate Social Responsibilty and Environmental Management, 12: 73-87.

White, M. A. (1996). Environmental Finance: Value and Risk in an Age of Ecology, Business Strategy and The Environment, 5: 198-206.

Yao, J. ve Ouyang, H. (2007). Dark-Side Evidence on Bank-Firm Relationship in Japan, Japan and The World Economy, 19: 198-213.

Yılmaz, D. Ö. (2007). Genel Turizm, Turizmde Temel Kavramlar ve Ilkeler. İçinde İçöz, O. (Editör) : 1-19 Ankara: Turhan Yayınevi. 